\title{
Performance of a Pilot Subsurface Flow Treatment Wetland System, Used for Arsenic Removal from Reverse Osmosis Concentrate, in the Municipality of Julimes, Chihuahua, Mexico*
}

Desempeño de un sistema piloto de humedales de tratamiento de flujo subsuperficial, utilizado para la remoción de arsénico del concentrado de ósmosis inversa, en el municipio de Julimes, Chihuahua, México

Submitted on: 3 May, 2019 | Accepted on: 27 January, 2020 | Published on: 04 December, 2020

Mario Alberto Olmos-Márquez

Universidad Autónoma de Chihuahua, México

ORCID: 0000-0002-5468-8010

Jesús Manuel Ochoa-Rivero

Universidad Autónoma de Chihuahua, Instituto Nacional de Investigaciones Forestales, Agrícolas y Pecuarias (INIFAP), México

ORCID: 0000-0003-0015-6593

María Teresa Alarcón-Herrera

Centro de Investigación en Materiales Avanzados, México

ORCID: 0000-0003-1168-8544

Eduardo Santellano-Estrada

Universidad Autónoma de Chihuahua, México

ORCID: 0000-0003-0884-0971

José Humberto Vega-Mares

Universidad Autónoma de Chihuahua, México

ORCID: 0000-0001-7488-3334

María Cecilia Valles-Aragón

Universidad Autónoma de Chihuahua, México

ORCID: 0000-0003-1694-763X

${ }^{*}$ Research article

${ }^{a}$ Corresponding author. E-mail: molmos@uach.mx

DOI: https://doi.org/10.11144/Javeriana.iued24.ppsf

How to cite this article:

M. A. Olmos, J. M. Ochoa-Rivero, M. T. Alarcón-Herrera, E. Santellano-Estrada, J. H. Vega-Mares, and M. C. Valles-Aragón, "Performance of a pilot subsurface flow treatment wetland system, used for arsenic removal from reverse osmosis concentrate, in the municipality of Julimes, Chihuahua, Mexico," Ing. Univ., vol. 24, 2020. https://doi.org/10.11144/Javeriana.ived24.ppsf 


\section{Abstract}

The objective of this study was to implement a pilot system of treatment wetlands, using phytoremediation as an alternative technology to remove arsenic from the concentrate of a reverse osmosis system. The pilot system was composed of two subsurface flow constructed wetlands, planted with Eleocharis macrostachya and Shoenoplectus americanus. The wetlands were fed concentrate from a reverse osmosis system for seven months, with an average flow of 962 Ld-1 and an average arsenic concentration of $0.241 \mathrm{mgL}^{-1}$. Removal rates between $43 \%$ and $86 \%$ were obtained for wetland 1 and between $35 \%$ and $79 \%$ for wetland 2 throughout the experiment. The two plant species developed normally despite the high levels of electrical conductivity in the range of 3584 to $5455 \mu \mathrm{scm}^{-1}$ in wetland intake waters. The pilot wetland system removed significant levels of arsenic from the reverse osmosis concentrate, resulting in arsenic levels in the output waters that meet Mexican standard for using water in agricultural irrigation.

\footnotetext{
Keywords: arsenic, reverse osmosis, concentrate, treatment wetlands.
}

\section{Resumen}

El objetivo de este estudio fue implementar un sistema piloto de humedales de tratamiento, utilizando la fitorremediación como tecnología alternativa para eliminar arsénico del concentrado de un sistema de osmosis inversa. El sistema piloto estaba integrado por dos humedales construidos de flujo subsuperficial, plantados con Eleocharis macrostachya y Shoenoplectus americanus. Los humedales de tratamiento se operaron durante 7 meses con el concentrado generado por un sistema de osmosis inversa, con un flujo promedio de $962 \mathrm{Ld}^{-1}$ y una concentración de arsénico promedio de $0.241 \mathrm{mgL}^{-1}$. Durante todo el tiempo de experimentación se obtuvieron eficiencias de remoción de arsénico entre $43 \%$ y $86 \%$ para el humedal 1 y entre $35 \%$ y $79 \%$ para el humedal 2. Las dos especies de plantas se desarrollaron de manera normal a pesar de los altos valores de conductividad eléctrica a la entrada de los humedales, en el rango de los 3584 a $5455 \mathrm{scm}^{-1}$. El sistema piloto de humedales propuesto mostró una remoción significativa del arsénico del concentrado del sistema de osmosis inversa, logrando que la concentración de arsénico en el agua de salida de los humedales cumpliera con la normatividad mexicana establecida para su uso en el riego agrícola.

Palabras clave: arsénico, osmosis inversa, concentrado, humedales de tratamiento. 


\section{Introduction}

Ground water has become an important source of drinking water as surface waters are drying up. It is estimated that $39 \%$ of the fresh water used in Mexico comes from ground waters in 635 aquifers, of which 105 are being overused and 32 have problems of salinity, while $44 \%$ of the population depends on groundwater as a source of drinking water [1]. In many places, groundwater is highly ionic as a result of natural geological formations that result in aquifers, including arsenic (As) [2]. The main sources of As in the environment (the hydrosphere, biosphere, and atmosphere) are minerals rich in As such as pyrite, which is released in water by hydrogeochemical factors [3], [4].

Strategies are needed to reduce the toxicity and availability of As to lower the health risks associated with direct consumption of As in contaminated water and indirect consumption through food cooked in or irrigated with contaminated waters. Some of the technologies available for removing As are oxidation, coagulation-flocculation, absorptions, ionic exchange, membrane-based, and phytoremediation. Reverse osmosis has been identified as ideal for small-scale water treatment systems to remove As [5] because it can be easily controlled and automated.

Membrane-based desalination, such as reverse osmosis systems (ROS), is used to treat brackish groundwater, because it is effective in eliminating almost all the elements dissolved in water. The main challenge for ROS is managing and minimizing concentrates [6], which are characterized by high salinity and high loads of accumulated contaminants. While coastal communities have access to seawater, which is widely used to treat concentrates, inland communities have more difficulty in accessing adequate water resources. The management of reverse osmosis concentrates depends on the quantity and quality of the water, its origin, as well as the geography and geology, regulations, costs, and potential environmental impacts. The current options for eliminating reverse osmosis concentrates in non-coastal cities include discharges in surface waters, sewage systems or deep wells, evaporation ponds, use in irrigation, and zero discharge using thermal evaporators and crystallizers [6], [7]. The first three options are convenient but pose the risk of contaminating water sources and habitats and interfering with water treatment installations because of incrustations and inhibition of biological processes because of increased salinity. Eliminating large quantities of reverse osmosis concentrates represents a waste of water resources, while some of the possible options are prohibitively expensive for non-coastal communities [7], [8]. As the requirements for permits to treat reverse osmosis concentrates become stricter, it will be more to crucial to development new treatment methods and beneficial uses of this type of water to reduce costs and environmental damage [9], [10]. The treatment of reverse osmosis concentrates can make more water available for use in irrigation in the context of water scarcity in arid climates. Potential water treatment problems with reverse osmosis include the concentration of feedwater contaminants, 
chemical wastes (acids, disinfectants, coagulants, and anticorrosive agents), and potentially toxic elements or metals from the natural dissolution of rocks, agricultural runoff, and mining [11], [12]. Consequently, the viable elimination of these contaminants continues to be a challenge.

Wetland-based water treatment systems have been used for decades because of their capacity to remove conventional contaminants from wastewater [13], even in highly saline waters [14]. Wetland systems have only recently been tested at an experimental scale to treat reverse osmosis concentrates [9], [12] for their beneficial reuse [15]. The use of wetlands to treat and reuse concentrates is gaining ground as a means to manage this type of waste [16], [17]. The objective of this study was to implement a pilot system of treatment wetlands, using phytoremediation as an alternative technology to remove As from the concentrate of a ROS to provide the local population with quality water for reuse, as well as to limit environmental pollution due to poor disposal of waste.

\section{Materials and Methods}

\section{Study Area}

The city of Julimes is located $85 \mathrm{~km}$ from the capital of Chihuahua State $\left(28^{\circ} 25^{\prime} 26^{\prime \prime} \mathrm{N}\right.$, $105^{\circ} 25^{\prime} 33^{\prime \prime} \mathrm{W}$ ) at an average altitude of 1296 masl (figure 1). The city covers an area of $2767.30 \mathrm{~km}^{2}$ [18]. According to the most recent census, there are 4959 inhabitants in the municipality [19]. The climate is dry and semi-warm, with a maximum temperature of 41.7 ${ }^{\circ} \mathrm{C}$ and a minimum of $-14.1{ }^{\circ} \mathrm{C}$, with an annual average temperature of $18.3{ }^{\circ} \mathrm{C}$. The average annual precipitation is between 200 and $300 \mathrm{~mm}$ [18]. 
Figure 1. Study area

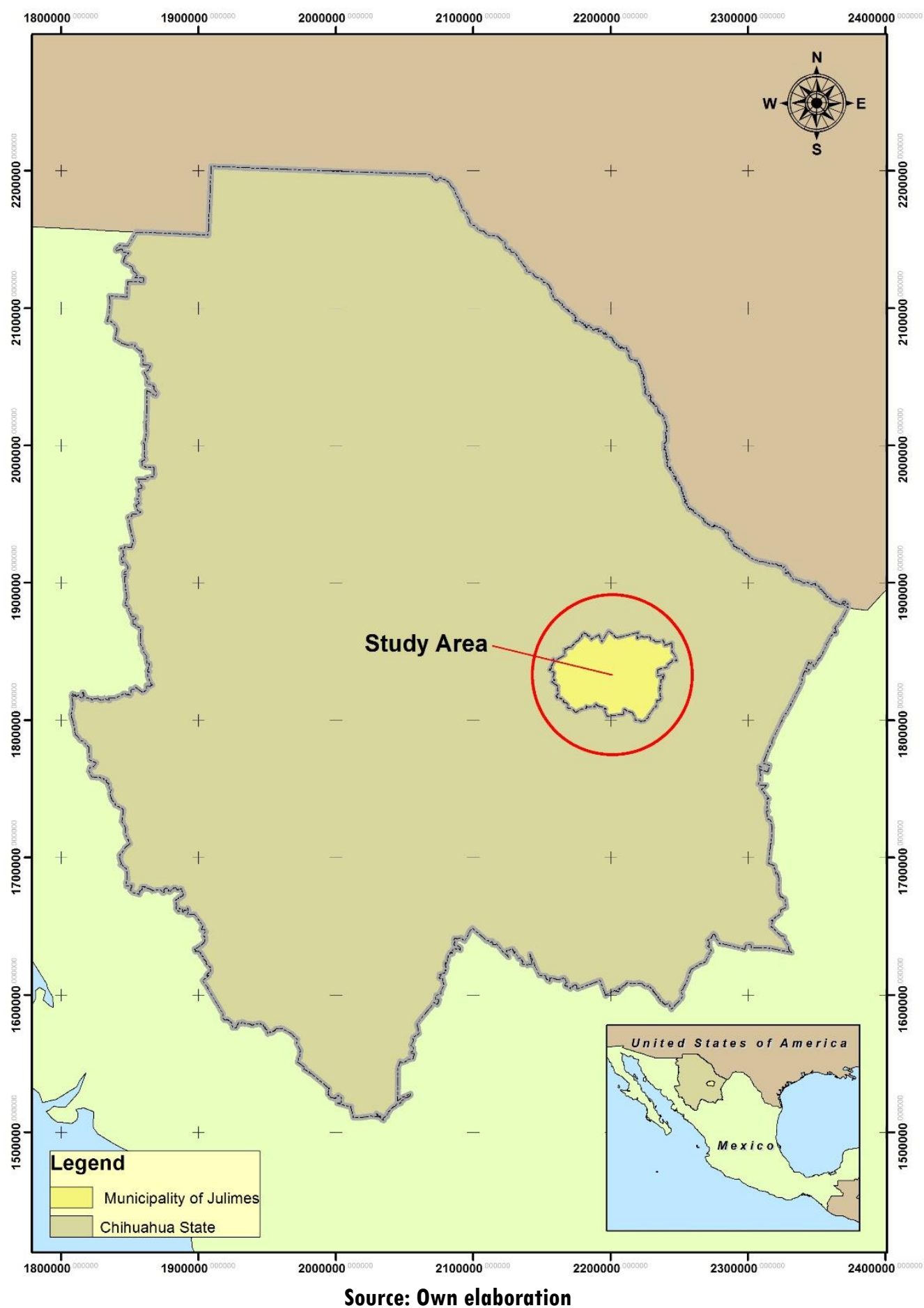




\section{Characterization of the Water from the Reverse Osmosis System}

Intake and output water of a reverse osmosis in a secondary school in the municipality of Julimes was sampled on a daily basis for one week in accordance with Mexican government standards (NMX-AA-003-2008). The samples were analyzed at the Mexican Geological Service for total As using mass plasma spectrometry (Perkin Elmer, Model NEXION 300D) (NMX-AA-131/1-SCFI-2008). Additionally, ultrasonic flow meters (EKKO Flow Q $2102^{\circledR}$ ) were placed at the intake and output points to measure daily water flows.

\section{Characterization of the Support Medium (Soil)}

The soil used as a support medium was characterized prior to applying it to the wetlands. The two samples were analyzed granulometrically in duplicate with one kilogram of soil from each wetland. This procedure is based on a sifting operation with a series of metal meshes (U. S. Standard Testing Sieve series), selected according to particle size. The determination was done manually for larger grains sizes and with Ro-Tap for finer particles. The chemical composition and main mineral components of the soil were determined by quantitative aluminosilicate determination and rock analysis by X-ray fluorescence spectrometry. The two studies were conducted in the soil laboratory of the Mexican Geological Service.

\section{Collecting and Acclimatizing Plants}

Samples of E. macrostachya (30 cm high) and $S$. americanus $(50 \mathrm{~cm}$ high) were collected

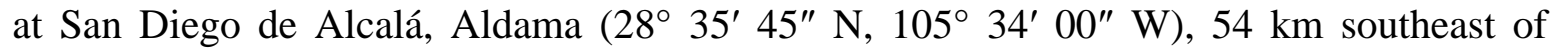
Chihuahua City and $44 \mathrm{~km}$ from the municipal head of Julimes. The site was selected from results of a project to identify plants suitable for phytoremediation [20]. The digging technique consisted of penetrating the soil down to $40 \mathrm{~cm}$ at $250 \mathrm{~cm}$ from the base to avoid damage to the roots. After removing the plants, they were placed in soil in $125 \mathrm{~L}$ highdensity polypropylene containers, which were filled with water from the extraction site before being transported. The roots were washed with water to remove impurities and

pebbles. The plants were placed in plastic flowerpots, with a $15 \mathrm{~cm}$ bed of river sand, which were then filled without compression with $15 \mathrm{~cm}$ of a mixture of the same sand and nitrogen fertilizer. A space was left to maintain a sheet of water (flood conditions). The plants were immediately watered and placed in an open greenhouse with shaded mesh $(50 \%)$. The plants were subsequently watered daily with drinking water in which no As had been detected. 


\section{Designing the Pilot Wetland Treatment System and Conducting the Experiment}

Based on a desired average flow of concentrate of $1451 \mathrm{~L}\left(1.45 \mathrm{~m}^{3}\right)$, a 3 to 1 ratio, and two wetlands to make efficient use of the space, we determined a required wetland surface area of $7.14 \mathrm{~m}^{2}$. The experiment took place over a period of seven months, from May to November 2017. A subsurface flow pilot wetland treatment system, consisting of two wetlands, was installed in a greenhouse $10 \mathrm{~m}$ long by $5 \mathrm{~m}$ wide and $3 \mathrm{~m}$ high. The wetlands were contained in fiber glass tanks $4.5 \mathrm{~m}$ long by $1.5 \mathrm{~m}$ wide by $1 \mathrm{~m}$ high and connected to each other in parallel. The support medium used for the two wetlands was silty sand (porosity $=0.35$ ). Both wetlands were planted with 9 groups of E. macrostachya (average 50 individuals per group, with a height of $0.30 \mathrm{~m}$ ) and 9 groups of $S$. americanus (average of 10 individuals per group, with a height of $0.50 \mathrm{~m}$ ). Each group of the two species were separated by $0.40 \mathrm{~m}$ horizontally and $0.50 \mathrm{~m}$ vertically. During the experiment, the wetlands were fed with concentrate generated by reverse osmosis, with an average As concentration of $0.241 \mathrm{mgL}^{-1}$ (minimum $0.106 \mathrm{mgL}^{-1}$ and maximum $0.306 \mathrm{mgL}^{-1}$ ) and an average flow of $962 \mathrm{Ld}^{-1}$ (minimum $613 \mathrm{Ld}^{-1}$ and maximum $2190 \mathrm{Ld}^{-1}$ ). A two-day water retention time was used based on the results from a previous study [21] in which a prototype experiment was conducted to treat synthetic water with As concentrations ranging from 0.05 to $0.5 \mathrm{mgL}^{-1}$ with a flow rate of $150 \mathrm{Ld}^{-1}$. The water treated by the wetland system was used for watering green areas of a school and a family garden (figure 2).

Figure 2. Diagram of the reverse osmosis and pilot wetland treatment system REVERSE OSMOSIS SYSTEM FOR DRINKING WATER \& PILOT SYSTEM FOR WATER RECOVERY

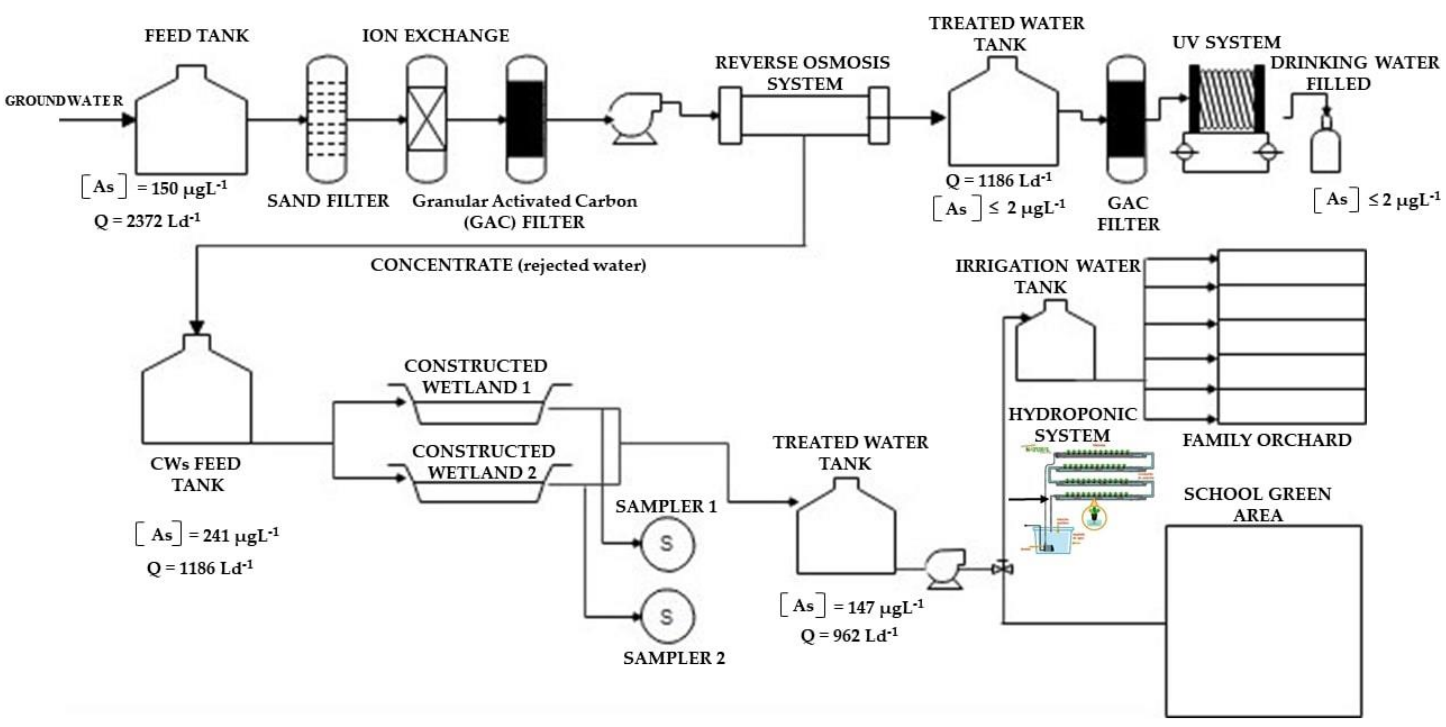

Source: Own elaboration 


\section{Water Sampling and Analysis}

Intake and output wetland waters were sampled weekly throughout the experiment to determine total As by mass plasma spectrometry (Perkin Elmer, Model NEXION 300D). The samples were also used to measure $\mathrm{pH}$ levels, electrical conductivity, and temperature with a portable multi-parametric meter (Thermo Scientific, Orion A325). Samples were collected daily in $750 \mathrm{~mL}$ plastic containers using two automatic samplers installed at the outtake points of the two wetlands to determine $\mathrm{pH}$, electrical conductivity, temperature, and total As using a rapid liquid method $(\mathrm{HACH})$ to obtain a reading of the daily behavior of the system.

\section{Monitoring Physical Plant Parameters}

The growth and reproduction of the two plant species were monitored weekly throughout the experiment by counting individual plants and measuring plant height. Plant stems and fruit were also assessed for any effects on cell tissue owing to necrosis or chlorosis owing to high concentrations of As and dissolved salts.

\section{Statistical Analysis}

The normality of the data was confirmed with the Shapiro-Wilk and D'Agostino-Pearson tests using XLSTAT $2018^{\circledR}$ software for EXCEL ${ }^{\circledR}$. The effect of the As removal process was then analyzed by a paired T-test (for non-independent pre- and post-situation samples) to test the null hypothesis. The difference between wetlands was tested by means of a variance analysis. The Pearson correlation coefficient was applied to analyze the linear interdependence between pairs of variables related to water quality. The latter three analyses were supported by UNIVARIATE, GLM, and CORR software SAS 9.0 ${ }^{\circledR}$, respectively. Additionally, As levels in reverse osmosis concentrates and output wetland waters were compared to regulatory standard using a simple hypothesis T-test comparing means of the samples to reference values. 


\section{Results}

\section{Characterization of the Reverse Osmosis Water}

Table 1 shows the results of daily characterizations of the intake water and concentrate conducted over one week.

Table 1. Average As concentrations and flows in intake and reverse osmosis concentrates

\begin{tabular}{lcccc}
\hline & $\begin{array}{c}\text { Intake flow } \\
(\mathbf{L})\end{array}$ & $\begin{array}{c}\text { Concentrate flow } \\
(\mathbf{L})\end{array}$ & $\begin{array}{c}\text { As in intake } \\
\left(\mathbf{m g L}^{-\mathbf{1}}\right)\end{array}$ & $\begin{array}{c}\text { As concentrate } \\
\left(\mathbf{m g L}^{-\mathbf{1}}\right)\end{array}$ \\
\hline Average & 2372 & 1451 & 0.099 & 0.140 \\
\hline Minimum & 1697 & 1116 & 0.097 & 0.127 \\
\hline Maximum & 3260 & 2096 & 0.105 & 0.153 \\
\hline \multicolumn{5}{c}{ Source: Own elaboration }
\end{tabular}

The average percentage of concentrate generated by reverse osmosis was $61 \%$ and the average increase in As concentration was $41 \%$. The average concentrate flow of the concentrate $\left(1451 \mathrm{Ld}^{-1}\right)$, was higher than the average flow of feedwater to the wetlands system $\left(962 \mathrm{Ld}^{-1}\right)$, which was due to the water pipe being plugged by incrustations of salt from the water. The average As levels determined when the water was characterized were much lower than the levels presented throughout the experiment, with averages of 0.099 and $0.241 \mathrm{mgL}^{-1}$, respectively.

\section{Characterization of the Support Medium}

The support medium used to fill the wetlands was silica sand. Dividing the sand grains into size categories, according to the granulometric analysis, the highest percentage $(22 \%)$ of grains belonged to the mesh size $-8+10(-2360+2000 \mu \mathrm{m})$, the T80 was $2062.72 \mu \mathrm{m}$, while the lowest percentage $(3.08 \%)$ was the -100 mesh $(-150 \mu \mathrm{m})$. The chemical composition of the soil in descending order of importance was $\mathrm{SiO}_{2}=76.65 \%, \mathrm{Al} 2 \mathrm{O} 3=$ $10.67 \%, \mathrm{~K}_{2} \mathrm{O}=3.70 \%, \mathrm{Fe}_{2} \mathrm{O}_{3}=3.08, \mathrm{Na}_{2} \mathrm{O}=2.65 \%, \mathrm{CaO}=1.50 \%, \mathrm{MgO}=0.45 \%$ and loss by calcination $=1.74 \%$.

\section{Performance of the Treatment Wetlands}

There were significant differences in As levels between intake and output waters of both wetlands $(\mathrm{p}<0.0001)$, without any statistically significant difference between the two 
wetlands $(\mathrm{p}=0.2314)$. This demonstrates the effectiveness of the proposed wetland system in removing As from the reverse osmosis concentrate. Figure 3 shows the behavior of As concentrations in wetland intake and output waters. The average As removal rates over the seven months of the experiment were $43 \%$ and $35 \%$, with maximum rates of $86 \%$ and $79 \%$ for $\mathrm{W} 1$ and $\mathrm{W} 2$, respectively, while the average As concentration in wetland intake waters was $0.241 \mathrm{mgL}^{-1}$, with a maximum value of $0.306 \mathrm{mgL}^{-1}$.

Arsenic removal was at its most efficient in both wetlands during the first four weeks. The higher initial removal rates were due to As retention in the support medium through absorption in silica and iron oxides. Arsenic retention subsequently decreased and remained lower throughout the rest of the experiment. This could have been due to the high level of water salinity, which resulted in high levels of osmotic pressure at the plant roots and prevented from retaining As. Arsenic concentrations in wetland output waters met with Mexican standard for use in agricultural irrigation $(\mathrm{p}<0.05)$, which was not the case for the concentrate $(\mathrm{p}>0.05)$.

Figure 3. Arsenic concentrations in W1 and W2 intake and output waters

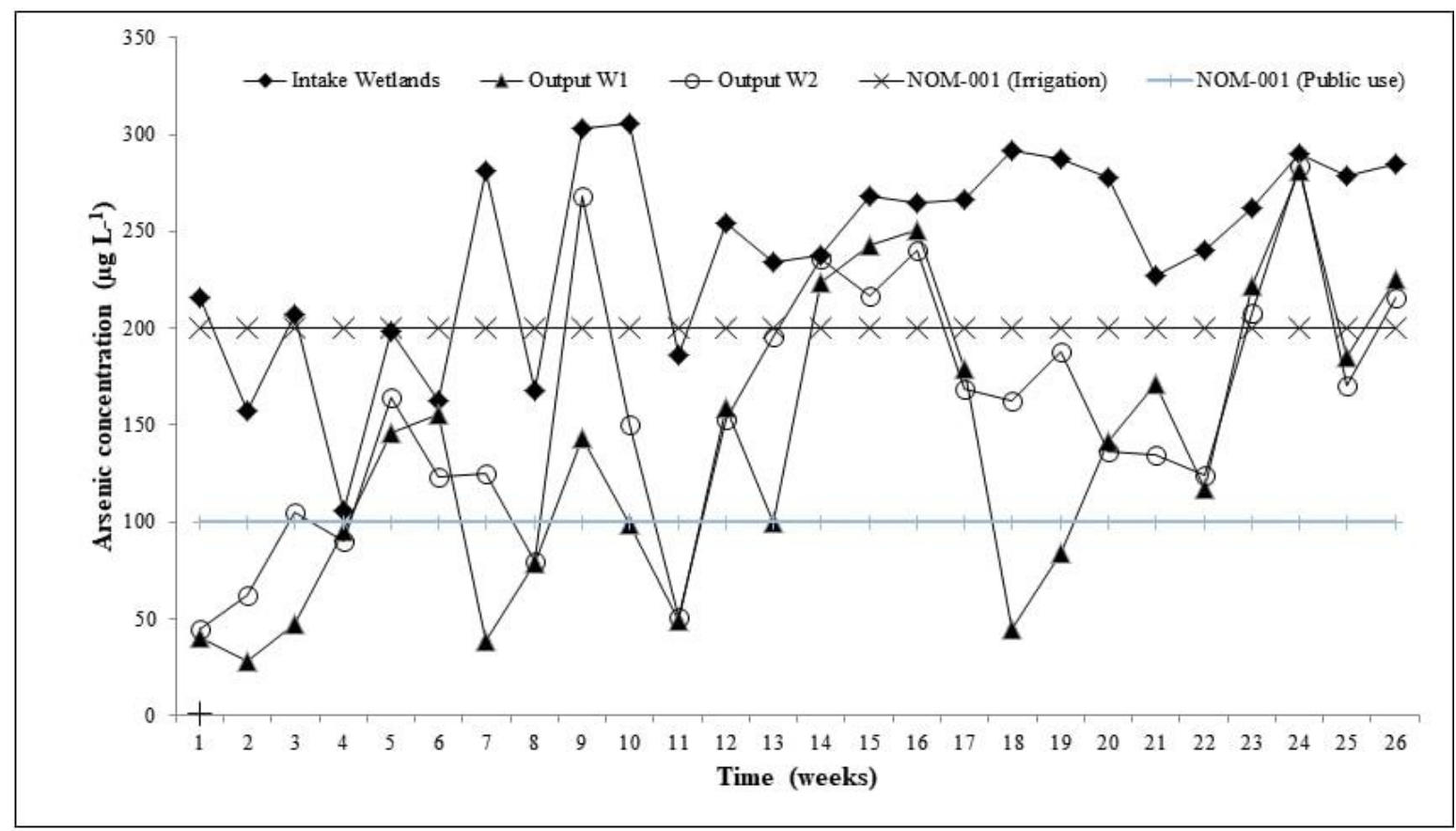

Source: Own elaboration

Table 2 shows the average concentrations of chloride $\left(\mathrm{Cl}^{-}\right)$, sodium $\left(\mathrm{Na}^{+}\right)$, and sulfate ions $\left(\mathrm{SO}^{4-}\right)$ and $\mathrm{EC}, \mathrm{pH}$ and temperature values in wetland intake and output waters. 
Table 2. Minimum, average, and maximum EC, $\mathrm{pH}$, temperature, and ion concentrations in $\mathrm{W} 1$ and $\mathrm{W} 2$ intake and output

\begin{tabular}{|c|c|c|c|c|c|c|c|c|c|c|c|c|}
\hline & \multicolumn{3}{|c|}{$\mathrm{CE}\left(\mu \mathrm{scm}^{-1}\right)$} & \multicolumn{3}{|c|}{ pH } & \multicolumn{3}{|c|}{$\mathbf{T}\left({ }^{\circ} \mathbf{C}\right)$} & $\mathrm{Cl}^{-}$ & $\mathbf{N a}^{+}$ & $\mathrm{SO}_{4}{ }^{-}$ \\
\hline & Min & Aver & Max & Min & Aver & Max & Min & Aver & Max & \multicolumn{3}{|c|}{$\left(\mathrm{mgL}^{-1}\right)$} \\
\hline Intake & 1708 & 4066 & 4920 & 7.21 & 7.70 & 8.10 & 18 & 28 & 41 & 485 & 4071 & 1450 \\
\hline W1 output & 1870 & 4004 & 4987 & 7.18 & 7.63 & 8.10 & 13 & 24 & 35 & \multirow{2}{*}{460} & \multirow{2}{*}{4340} & \multirow{2}{*}{1326} \\
\hline W2 output & 1855 & 4107 & 4997 & 7.11 & 7.62 & 8.11 & 14 & 24 & 35 & & & \\
\hline
\end{tabular}

There were no significant differences between intake and output $\mathrm{CE}$ and $\mathrm{pH}$ values ( $\mathrm{p}>$ $0.05)$. In contrast, intake and output water temperature differed $(p=0.0008$ and $p=0.0005$ for wetlands 1 and 2, respectively). The high concentrations of chloride and sodium concentrations were due to a salt-based pretreatment $(\mathrm{NaCl})$ to reverse osmosis to reduce intake water hardness and to protect the membranes. Sulfate ions were of geological origin. The three ions are retained by reverse osmosis at levels of $90 \%$. Together with As, these ions contribute to the high levels of dissolved solids and the high level of electrical conductivity of the concentrates.

EC values in wetland intake waters indicated high concentrations of dissolved ions throughout the experiment. EC intake levels were high, which is characteristic of reverse osmosis concentrates. Output levels were higher than Intake levels, reflecting water loss by evapotranspiration by wetland plants. One way to reduce EC levels in wetland intake waters is to dilute the reverse osmosis concentrate with effluent from primary or secondary municipal wastewater treatment systems. The $\mathrm{pH}$ values at output for both wetlands were slightly alkaline, although with a decrease in this parameter from the Intake level. This decrease could be due to acid exudates generated by the plant roots.

\section{Physical Behavior of the Plants}

Qualitative observations of the state of the wetland plants were made throughout the experiment. The plants showed no signs of mortality, injury, or stress, including darkening of the tips, shoot necrosis, pigment loss in buds, or other indicators of mortality or injury. Normal flowering and fruiting were observed. The average growth of E. macrostachya and S. americanus species were respectively $1.20 \mathrm{~m}$ and $1.50 \mathrm{~m}$ (figure 4 ). 
Figure 4. Development of $E$. macrostachya and S. americanus during the experiment

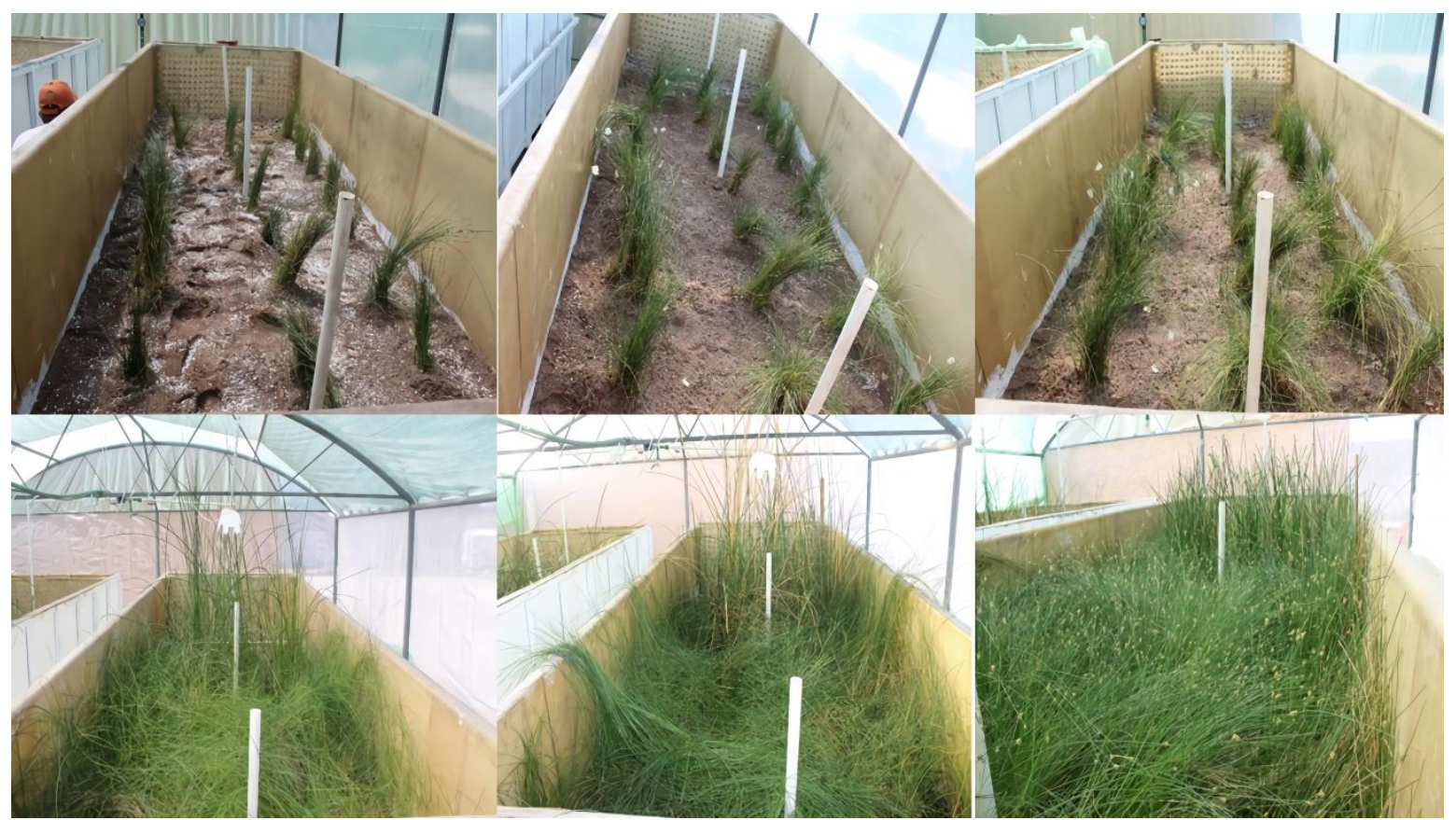

Source: Own elaboration

\section{Statistical Analysis}

Linear interdependence among variables related to water quality. The results of an analysis of the linear correlations among the physiochemical variables related to water quality, including As levels, are shown in table 3, with their respective significance value.

Table 3. Correlation coefficients among the variables involved in the experiment

\begin{tabular}{|c|c|c|c|c|}
\hline Variable & $\mathbf{P H}$ & CE & TC & As \\
\hline $\mathrm{PH}$ & 1 & -0.2753 & 0.0315 & -0.0364 \\
\hline p-value & & 0.1735 & 0.8788 & 0.8597 \\
\hline $\mathrm{CE}$ & & 1 & -0.2247 & 0.4343 \\
\hline$p$-value & & & 0.2697 & 0.0266 \\
\hline TC & & & 1 & -0.3686 \\
\hline$p$-value & & & & 0.0639 \\
\hline As & & & & 1 \\
\hline
\end{tabular}

Source: Own elaboration 
A direct and significant linear relationship was found between electrical conductivity and the As level in water $(\mathrm{r}=0.4343, \mathrm{p}=0.0266)$, such that electrical conductivity explains $18.86 \%\left(\mathrm{R}^{2}=0.1886\right)$ of As variation in water. Water temperature showed an indirect linear relationship to the As concentration in water $(r=-0.3686, p=0.639)$, that is, the higher the temperature, the lower the As concentration.

\section{Discussion}

A recent study [22] tested the capacity of Juncus effusus, and Cyperus haspan to remove As from concentrates from reverse osmosis wetland systems and achieved maximum removal rates of $50 \%$ and $80 \%$ for $J$. effusus and C. haspan, respectively, when the average As concentration and level of conductivity in Intake waters were $0.095 \mathrm{mgL}^{-1}$ and $1394 \mu \mathrm{S} \mathrm{cm}^{-}$ ${ }^{1}$ respectively. It can be observed that $E$. macrostachya and $S$. americanus perform better than J. effusus, and C. haspan in removing As, with maximum rates of $86 \%$.

Other studies have shown that seawater salt inhibits absorption of metals and nutrients by halophyte plants [23]. It has been reported that increased water salinity decreases the metal accumulation capacity of Elodea canadensis and Potamogeton natans [24]. Likewise, salinity causes nutrient deficiency or imbalance in plants due to the competition of $\mathrm{Cl}^{-}$and $\mathrm{Na}^{+}$with nutrients like $\mathrm{K}^{+}, \mathrm{Ca}^{+2}$, and $\mathrm{NO}^{3-}$ [25]. Although E. macrostachya is not considered a halophyte, there was no apparent physical damage to cell tissue or any effect on growth and reproductive function. However, the capacity of the plant to remove As was impaired, as occurred in prototype study [21] in which the As concentrations were higher, but the salinity (EC) of the wetland feedwater was lower than $1000 \mu \mathrm{S} \mathrm{cm}{ }^{-1}$. The As removal rate in that study was greater than $90 \%$ and was stable for a year.

The study of Chakraborti [9] focused on a pilot wetland system to treat concentrate from reverse osmosis of secondary effluent found a similar behavior of these field parameters, with Intake and output values respectively of 7.37 and $7.37(\mathrm{pH}), 15880$ and 17800 (EC), and $18.16^{\circ} \mathrm{C}$ and $14.91{ }^{\circ} \mathrm{C}$ (temperature). The increase in EC in this study was caused by an increase in chloride ions and evapotranspiration, while in our study, sodium ions increased, which, together with the effects of evapotranspiration, could account for the increase in EC. The study by [9] reported a slight decrease in $\mathrm{pH}$, as was observed in this study, which is attributed to acid exudates by plant roots. In respect to temperature, the experiment took place in summer and autumn, when temperatures tend to be high, so wetland Intake water temperatures tended to be higher than output temperatures, which was due to the fact that water entered the system from an open tank heated directly by sunlight, while wetlands were inside a greenhouse shaded from the sun. Also, the support medium contributes to reducing water temperature by convection. 
A reverse osmosis wetland system in Goodyear, Arizona, planted with alkali sacaton grass, salt grass, cattails, and Olney's three-square rushes obtained As removal rates of $71 \%$ in summer and $50 \%$ in winter. However, the As Intake level was significantly lower than the levels in our experiment. A problem identified in other studies is that not only does wetland treatment not reduce levels of total dissolved solids (TDS) from concentrates, but in fact TDS levels in wetland output may be higher than the intake levels, which occurred in the case of our study. This occurs because wetland treatment eliminates only insignificant levels of salts (sulfates and chlorides), while evaporation rates are usually high, especially in the summer, which is reflected in a lower output flow with higher TDS levels in the intake concentrate [26].

\section{Conclusions}

The pilot wetland water treatment system planted with E. macrostachya and S. americanus had a significant impact in removing As from reverse osmosis concentrate. The output water from the wetlands met with Mexican standards for water use for agricultural irrigation.

Electrical conductivity and water temperature had the most linear relationships to As levels in the reverse osmosis concentrate of all the water quality parameters, so they can be key indicators for the monitoring of this pollutant.

Constructed wetlands can be a viable alternative for removing As from reverse osmosis concentrate. However, tests are necessary with wetlands in series and with dilution of treated wastewater to reduce the salinity. E. macrostachya and S. americanus are tolerant to high levels of salinity, although the capacity of their roots to remove As is seriously affected.

\section{Acknowledgment}

This research was carried out thanks to funding from the National Science and Technology Council (CONACYT), as part of the funding program on attention to national problems, 2014 (Project PDCPN-2014-248102) 


\section{References}

[1] Comisión Nacional del Agua (Conagua). Estadísticas del agua en México, 2017. Available: http://sina.conagua.gob.mx/publicaciones/EAM_2017.pdf.

[2] L. F. Greenlee, D. F. Lawler, B. D. Freeman, B. Marrot, and P. Moulin, "Reverse osmosis desalination: Water sources, technology, and today's challenges," Water Res., vol. 43, no. 9, pp. 2317-2348, 2009. doi: 10.1016/j.watres.2009.03.010

[3] P. Mondal, C. B. Majumder, and B. Mohanty, "Laboratory based approaches for arsenic remediation from contaminated water: Recent developments," J. Hazard. Mater., vol. 137, no. 1, pp. 464-479, Sept. 2006. doi: 10.1016/j.jhazmat.2006.02.023

[4] J. Bundschuh et al., "Arsenic removal from groundwater of the Chaco-Pampean Plain (Argentina) using natural geological materials as adsorbents," J. Environ. Sci. Health., vol 46, no. 11, pp. 12971310, 2011. doi: 10.1080/10934529.2011.598838

[5] S. Velizarov, J. Crespo, and M. Reis, "Removal of inorganic anions from drinking water supplies by membrane bio/processes," Rev. Environ. Sci. Biotechnol., vol. 3, no. 4, pp. 361-380, 2004. doi: $10.1007 / \mathrm{s} 11157-004-4627-9$

[6] M. Mickley, "Treatment Wetland, Desalination and Water Purification Research and Development Program Report no. 155. US Department of the Interior, Bureau of Reclamation," 2009. Available: https://www.usbr.gov/research/dwpr/reportpdfs/report155.pdf. Accessed on: Apr. 9, 2015.

[7] P. Xu, T. Y. Cath, A. P. Robertson, M. Reinhard, J. O. Leckie, and J. E. Drewes, "Critical review of desalination concentrate management, treatment and beneficial use," Environ. Eng. Sci., vol. 30, no. 8, pp. 502-514. doi: 10.1089/ees.2012.0348

[8] World Health Organization (WHO), Desalination for Safe Water Supply: Guidance for the Health and Environmental Aspects Applicable to Desalination. Geneva: Public Health and the Environment, World Health Organization, 2007.

[9] R. K. Chakraborti, J. S. Bays, Ng. Thien, L. Balderrama, and T. Kirsch, "A pilot study of a subsurface-flow constructed wetland treating membrane concentrate produced from reclaimed water," Water Sci. Technol., vol. 72, no. 2, pp. 260-268, 2015. doi: 10.2166/wst.2015.201

[10] A. Pérez-González, M. Urtiaga, R. Ibáñez, and I. Ortiz, "State of the art and review on the treatment technologies of water reverse osmosis concentrates," Water Res., vol. 46, no. 2, pp. 267-283, 2012. doi: 10.1016/j.watres.2011.10.046 PMID: 22119366

[11] M. Chapman, F. Leitz, E. Abart, B. Boegli, and K. Linton, "The Desalting and Water Treatment Membrane Manual: A Guide to Membranes for Municipal Water Treatment," US Bureau of Reclamation, Water Treatment Technology Program, Report no. 29, 2nd ed., Denver, CO, 1998. Available: https://www.usbr.gov/research/dwpr/reportpdfs/report029.pdf

[12] B. van der Bruggen, L. Lejon, and C. Vandecasteele, "Reuse, treatment, and discharge of the concentrate of pressure-driven membrane processes," Environ. Sci. Technol., vol. 37, no. 15, pp. 3733-3738, 2003. Available: https://doi.org/10.1021/es0201754

[13] R. H. Kadlec and S. Wallace, Treatment Wetlands, 2nd ed. Boca Raton, FL: CRC, 2009.

[14] J. M. Webb, R. Quinta, S. Papadimitriou, L. Norman, M. Rigby, D. N. Thomas, and L. Le Vay, "Halophyte filter beds for treatment of saline wastewater from aquaculture," Water Res., vol. 46, no. 16, pp. 512-5114, 2012. doi: 10.1016/j.watres.2012.06.034

[15] J. Bays, P. Frank, K. Ortega, "Oxnard's Membrane Concentrate Pilot Wetlands Project," in Proceedings 2007 Water Reuse Symposium. Tampa FL, 2007, session A-5.

[16] CW2M HILL and Mickley and Associates, Inc., "Beneficial and Non-traditional Use of Membrane Concentrate", Water Reuse Foundation, Project 02-006b-01, Alexandria, VA, 2006.

[17] J. Kepke, J. Bays, and J. Lozier, "Concentrate treatment using wetlands," Water, vol. 36, no. 7, pp. 57-63, 2009. Available: https://kestrel-inc.com/wp-content/uploads/2013/04/Water-Nov09_Kepke4.pdf 
[18] Instituto Nacional para el Federalismo y Desarrollo Municipal (Inifed), Índice de desarrollo municipal básico, $2005 . \quad$ Available https://www.gob.mx/cms/uploads/attachment/file/103592/DR_0831.pdf

[19] Instituto Nacional de Estadistica, Geografia e Informática (Inegi), "Julimes." Available: www.inegi.org.mx/app/buscador/default.html?q=julimes\#tabMCcollapse-Indicadores. Accessed on March 13, 2010.

[20] O. G. Núñez-Montoya, "Evaluation of three native species from Chihuahua desert for use in phytoremediation," Terra Latinoamericana, vol. 25, no. 1, pp. 35-41, 2007.

[21] M. A. Olmos-Márquez, M. T. Alarcón-Herrera, and I. R. Martín-Domínguez, "Performance of Eleocharis macrostachya and its importance for arsenic retention in constructed wetlands," Environ. Sci. Pollut. Res., vol. 19, no. 3, pp. 763-771, 2012. doi: 10.1007/s11356-011-0598-x

[22] C. Corroto, A. Iriel, E. Calderón, A. Fernández-Cirelli, and A. Pérez-Carrera, "Humedales construidos utilizados para la remoción de arsénico del agua," in Libro de Memorias IV Conferencia Panamericana de Sistemas Wetlands, 15-18 de mayo, 2018, pp. 92-95. Available: http://wetlandsconstruidos.blogspot.com/2018/11/libro-de-memorias-iv-conferencia.html?m=1

[23] Y. Liu, Y. J. Liu, "Biosorption isotherms, kinetics and thermodynamics," Sep. Purif. Technol., vol. 61, no. 3, pp. 229-242, 2008. doi: 10.1016/j.seppur.2007.10.002

[24] A. Fritioff, L. Kautsky, and M. Greger, "Influence of temperature and salinity on heavy metal uptake by submersed plants," Environ. Pollut., vol. 133, no. 2, pp. 265-274, 2005. Available: https://doi.org/10.1016/j.envpol.2004.05.036

[25] Y. Hu and U. Schmidhalter, "Drought and salinity: A comparison of their effects on mineral nutrition of plants," J. Plant Nutr. Soil Sci., vol. 168, 541-549, 2005. Available: https://www.semanticscholar.org/paper/Drought-and-salinity\%3A-A-comparison-of-their-effectsHu-Schmidhalter/35f390b4e2d9bcced12b32e32bb7fc6b6f61effc

[26] T. Poulson, R. Rhodes, J. Bays, and M. Hwang, "Regulating wetlands pilot study for concentrate management," Science and Technology Program, 2012, Report no. 3699. Available:

http://www.usbr.gov/research/projects/download_product.cfm?id=520. 